\title{
A comparative study on the nutritional value of three Polychaete species used in Shrimp Aquaculture.
}

\section{Un estudio comparativo sobre el valor nutricional de tres especies de poliquetos utilizadas en la acuicultura del camarón}

\author{
Bharath Jayaseelan, Priya Adikesavan and Stella Chelladurai* \\ Department of Oceanography and Coastal Area studies, Alagappa University, Thondi campus, \\ Thondi-623409, India. \\ *Author for correspondence: stella2004@rediffmail.com
}

\begin{abstract}
The potential use of polychaete worms are as a dietary source of protein, lipid, amino acids, and vitamins for aquaculture species and also used as alternative feeds of fish meal and fish oils. Many recent studies have been documented the nutritional benefits of polychaetes for aquaculture species, for their satisfactory food intake and reproductive performance in brood stock. Most of the polychaetes were used in hatcheries are wild caught. The commercial harvesting of polychaetes may leads to the disturbance in the benthic community and the ecosystem and also may leads to the depleting population in the ecosystem. Further the development of polychaete culture is therefore of economic importance beyond that the associated bait supply industry which is acted as the initial catalyst for this development. Hence, the present study has been made with three different polychaete species, to assess the nutritional value of the three species, one was imported (Nereis virens) and two locally available species (Perenereis cultrifera and Glycera $\mathrm{sp}$ ) for commercial uses in the shrimp aquaculture industry. The samples were collected from mandapam and Palk Bay Area and these samples were oven-dried and powdered. All the samples were analyzed and calculated in dry weight per 100 grams of sample. Moisture content was calculated by loss of drying (LOD) method. Protein and amino acids were estimated by Appendix IV (British Pharmacopeia 2007), and detailed amino acid profile was assessed by HPLC. Carbohydrates were determined by gravimetry method from Appendix IV in Volume 3 Indian Pharmacopeia (2007). Total fatty acid and fatty acid profile were estimated through gas chromatography based on British Pharmacopeia (2007). Minerals were analyzed by flame photometry and atomic spectrometry (Indian Pharmacopeia, 2007; US pharmacopeia by Lawrence Evans, USP 29 NF 22 vol. 28). Vitamins were determined by assay method using liquid chromatography in US pharmacopeia (Lawrence Evans, USP 29 NF 22 vol. 28). Ash content was estimated in a tared silica crucible at a temperature of 400 to $500^{\circ} \mathrm{C}$ in a muffle furnace. Fibers was estimated by an enzymaticgravimetric method followed by AOAC method 985.29 (1990). In the present study, among the three polychaete species, the maximum moisture content was recorded in Perinereis cultrifera $(5.60 \mathrm{~g})$ followed by Glycera sp $(5.34 \mathrm{~g})$ and Nereis virens $(3.89 \mathrm{~g})$ and the maximum value of protein content was recorded in $P$. cultrifera $(53.62 \mathrm{~g})$ followed by Glycera sp $(50.50 \mathrm{~g})$ and $N$. virens $(49.04 \mathrm{~g})$. The maximum total fatty acid content was recorded in $N$. virens $(32.31 \mathrm{~g})$ followed by Glycera sp $(20.99 \mathrm{~g})$ and $P$. cultrifera $(11.99 \mathrm{~g})$. The result of major fatty acids profile, showed that the Saturated Fatty Acid (SFA) content was higher when it compare to PUFA and MUFA in all three polychaetes . The maximum ash content was recorded in Glycera $\mathrm{sp}(20.32 \mathrm{~g})$ followed by $N$. virens $(11.73 \mathrm{~g})$ and $P$. cultrifera $(10.91 \mathrm{~g})$ and the maximum carbohydrate content was recorded in $P$. cultrifera $(17.53 \mathrm{~g})$ followed by $N$. virens $(2.67 \mathrm{~g})$ and
\end{abstract}


Glycera sp (2.04 g). In this study, EAA was recorded higher content when it compared to NEAA in all the three species of polychaete. In the EAA the most dominant amino acids are lysine, arginine, and isoleucine and in the NEAA are cysteine, alanine, asparagine, and aspartic acid whereas the lesser EAA and NEAA are methionine and serine, respectively. In vitamin study, $P$. cultrifera, $N$. virens and Glycera sp showed higher content of vitamins $A, B 1$, and $E$ and less in vitamin $\mathrm{C}$. Mineral content was dominant with chloride of all the three species of polychaete.

Key words : Polychaete worms, Perenereis species, fatty acids. amino acids, Minerals.

\section{RESUMEN}

El uso potencial de gusanos poliquetos es como fuente dietética de proteínas, lípidos, aminoácidos y vitaminas para especies de acuicultura y también se utiliza como alimento alternativo de harina de pescado y aceites de pescado. Se han documentado muchos estudios recientes sobre los beneficios nutricionales de los poliquetos para las especies de acuicultura, por su ingesta satisfactoria de alimentos y su desempeño reproductivo en reproductores. La mayoría de los poliquetos que se utilizaron en los criaderos se capturan en el medio silvestre. La recolección comercial de poliquetos puede provocar perturbaciones en la comunidad bentónica y el ecosistema y también puede conducir al agotamiento de la población en el ecosistema. Además, el desarrollo del cultivo de poliquetos es, por lo tanto, de importancia económica más allá de la industria asociada de suministro de cebos, que actúa como catalizador inicial de este desarrollo. Por lo tanto, el presente estudio se ha realizado con tres especies de poliquetos diferentes, para evaluar el valor nutricional de las tres especies, una fue importada (Nereis virens) y dos especies disponibles localmente (Perenereis cultrifera y Glycera $\mathrm{sp}$ ) para usos comerciales en la acuicultura de camarón. industria. Las muestras se recolectaron de mandapam y Palk Bay Area y estas muestras se secaron al horno y se pulverizaron. Todas las muestras se analizaron y calcularon en peso seco por 100 gramos de muestra. El contenido de humedad se calculó mediante el método de pérdida de secado (LOD). Las proteínas y los aminoácidos se estimaron mediante el Apéndice IV (British Pharmacopeia 2007), y el perfil detallado de aminoácidos se evaluó mediante HPLC. Los carbohidratos se determinaron mediante el método de gravimetría del Apéndice IV en el Volumen 3 de la Farmacopea India (2007). El perfil de ácidos grasos y ácidos grasos totales se estimó mediante cromatografía de gases según la Farmacopea Británica (2007). Los minerales se analizaron mediante fotometría de llama y espectrometría atómica (Indian Pharmacopeia, 2007; farmacopea de EE. UU. Por Lawrence Evans, USP 29 NF 22 vol. 28). Las vitaminas se determinaron mediante un método de ensayo usando cromatografía líquida en la farmacopea de Estados Unidos (Lawrence Evans, USP 29 NF 22 vol. 28). El contenido de cenizas se estimó en un crisol de sílice tarado a una temperatura de 400 a $500^{\circ} \mathrm{C}$ en un horno de mufla. Las fibras se estimaron mediante un método enzimático-gravimétrico seguido del método AOAC 985.29 (1990). En el presente estudio, entre las tres especies de poliquetos, el contenido máximo de humedad se registró en Perinereis cultrifera $(5.60 \mathrm{~g})$ seguido de Glycera sp $(5.34 \mathrm{~g})$ y Nereis virens $(3.89 \mathrm{~g})$ y el valor máximo de contenido de proteína se registró en $\mathrm{P}$. cultrifera $(53,62 \mathrm{~g})$ seguida de Glycera sp $(50,50 \mathrm{~g})$ y $\mathrm{N}$. virens $(49,04 \mathrm{~g})$. El contenido máximo de ácidos grasos totales se registró en $\mathrm{N}$. virens $(32,31 \mathrm{~g})$ seguido de Glycera sp $(20,99 \mathrm{~g})$ y P. cultrifera $(11,99 \mathrm{~g})$. El resultado del perfil de ácidos grasos principales mostró que el contenido de ácidos grasos saturados (SFA) era mayor en comparación con PUFA y MUFA en los tres poliquetos. El contenido máximo de cenizas se registró en Glycera sp $(20,32 \mathrm{~g})$ seguido de $\mathrm{N}$. virens $(11,73 \mathrm{~g})$ y P. cultrifera $(10,91$ g) y el contenido máximo de carbohidratos se registró en $\mathrm{P}$. cultrifera $(17,53 \mathrm{~g})$ seguido de $\mathrm{N}$. virens $(2,67 \mathrm{~g})$ y Glycera sp $(2,04 \mathrm{~g})$. En este estudio, se registró un mayor contenido de EAA 
en comparación con NEAA en las tres especies de poliquetos. En el EAA, los aminoácidos más dominantes son lisina, arginina e isoleucina y en el NEAA son cisteína, alanina, asparagina y ácido aspártico, mientras que los EAA y NEAA menores son metionina y serina, respectivamente. En el estudio de vitaminas, P. cultrifera, N. virens y Glycera sp mostraron un mayor contenido de vitaminas A, B1 y E y menos de vitamina C. El contenido de minerales fue dominante con el cloruro de las tres especies de poliquetos.

Palabras clave: gusanos poliquetos, especies de Perenereis, ácidos grasos. aminoácidos, minerales

\section{INTRODUCTION}

Polychaete worms or marine worms are belonging to the phylum Annelida and also the dominant group of the organisms in the benthic marine environments (Stoner and Acevedo, 1990). Navedo and Masero (2007) reported that the Polychaete worms are play a major role in the marine food chains and it was found in almost all marine ecosystems. Scaps (2003) stated that the worms are regular source of food for all vertebrates, and invertebrates. Polychaetes perform many important environmental services such as sediment bioturbation (Scaps, 2002), decomposition of organic matter, breaking down of toxic ammonia-based compounds in the sediment (Kristensen et al., 1985), release of nutrients back to the environment (Scaps, 2002, Batista et al., 2003) and aeration of the sediment (Beesley et al., 2000). Shiau (1998) reported that the nutritional requirements of brood stock are less understood than those of the other penaeid shrimps production. Intensive study has been made to develop the suitable artificial diet for brood stock maturation (Coman et al., 2007; Marsden et al., 1997; Meunpol et al., 2005). Generally, in hatcheries, the fresh feed was used for brood stock growth, and these fresh feeds consist of squid, oysters, krill, artemia, and polychaetes. In the shrimps hatcheries the polychaetes worms are the most preferred food for healthy shrimp brood stocks maintenance. Soraphat Panakorn (2015) reported that the polychaetes are produced beneficial enzymes, amino acids, and hormones to stimulate the reproduction. Therefore, the live polychaetes are extensively used as feed in aquaculture industry, which is results in excellent source of polyunsaturated fatty acids (PUFAs), and hence the nereid worms are commonly called as omega worms due to their high content of omega-3 ( $\omega-3)$ PUFA (Lytle et al., 1990; Olive et al., 1992, Murugesan et al., 2011). The commercial value of the most exploited species of polychaetes has been documented by various authors (Klawe and Dickie, 1957; Creaser et al., 1983; Sarda Borroy, 1989; Chen, 1990). In India, the collection of polychaetes has emerged as an artisanal fishery in many coastal states and the annual consumption of these polychaetes by shrimp hatcheries is estimated to be about 6 to 20 tonnes (Vijayan et al., 2005).

The potential use of polychaete worms are as a dietary source of protein, lipid, amino acids, and vitamins for aquaculture species and also used for alternative feeds of fish meal and fish oils (Olive, 1999). Many recent studies have been documented the nutritional benefits of polychaetes for aquaculture species, for their satisfactory food intake and reproductive performance in brood stock sole (Cardinaletti et al. 2009), provision of PUFAs like AA, EPA, and $\mathrm{DHA}$, and the high $\mathrm{n} 3: \mathrm{n} 6$ ratio that helps in fertilization, hatch rates and spawning frequency in the shrimp Penaeus sp brood stock (Huang et al. 2008). Most of the polychaetes used in hatcheries are wild caught. The commercial harvesting of polychaetes may leads to the disturbance in the benthic community and the ecosystem (Gambi et al., 1994). The continuous harvesting of polychates from the wild may leads to the depleting population in the ecosystem. 
Further the development of polychaete culture is therefore of economic importance beyond that the associated bait supply industry which is acted as the initial catalyst for this development (Olive, 1999). Hence, the present study has been made with three different polychaete species, to assess the nutritional value of the three species, one from imported (Nereis virens) and two locally available species (Perenereis cultrifera and Glycera sp) for commercial uses of the shrimp aquaculture industry.

\section{MATERIALS AND METHODS}

This study was made with three different polychaete species for analysis: Nereis virens was imported from the Netherlands; Perinereis cultrifera and Glycera sp were collected from Mandapam coast and Palk Bay. The samples were collected by digging using shovel, and the polychaetes were carefully handpicked and washed gently in seawater and were starved for two days to clear the digestive tract before drying. The samples were oven-dried and powdered. All the samples were analyzed and calculated in dry weight per 100 grams of sample. Moisture is calculated by loss of drying (LOD) method by taking known initial weight of sample was accurately weighed in a tared dish and dried in an oven at $105^{\circ} \mathrm{C}$ for 1 hour or constant weight. It was cooled in a desiccator and weighed. LOD was calculated with reference to the amount of dried powder initially taken. Protein and amino acids were estimated by Appendix IV (British Pharmacopeia 2007), and detailed amino acid profile was assessed by HPLC. Carbohydrates were determined by gravimetry method from Appendix IV in Volume 3 Indian Pharmacopeia (2007). Total fatty acid and fatty acid profile were estimated through gas chromatography based on British Pharmacopeia (2007). Minerals were analyzed by flame photometry and atomic spectrometry (Indian Pharmacopeia, 2007; US pharmacopeia by Lawrence Evans, USP 29 NF 22 vol. 28). Vitamins were determined by assay method using liquid chromatography in US pharmacopeia (Lawrence Evans, USP $29 \mathrm{NF} 22$ vol. 28). Ash content is calculated by $1 \mathrm{~g}$ of sample accurately weighed which was incinerated in a tared silica crucible at a temperature of 400 to $500^{\circ} \mathrm{C}$ in a muffle furnace until it turns white, indicating the absence of carbon. Ash was cooled in a desiccator and weighed without delay, and the percentage was calculated on the basis of sample taken initially. Fibers was estimated by an enzymatic-gravimetric method followed by AOAC method 985.29 (1990).

\section{RESULT AND DISCUSSIONS}

In the present study, among the three polychaete species, the maximum moisture content was recorded in Perinereis cultrifera ( $5.60 \mathrm{~g})$ followed by Glycera sp $(5.34 \mathrm{~g})$ and Nereis virens $(3.89 \mathrm{~g})$. The maximum value of protein content was recorded in $P$. cultrifera $(53.62 \mathrm{~g})$ followed by Glycera sp $(50.50 \mathrm{~g})$ and $N$. virens $(49.04 \mathrm{~g})$. This similar observation has been made in Perinereis cultrifera from Egyptian Mediterranean Coast (Dorgham et al., 2015), in P.nuntia (Techaprempreecha et al., 2011) and N. virens (Brown et al., 2011). In the present study the fatty acids were estimated in all the three species of polychaete. The maximum total fatty acid content was recorded in $N$. virens $(32.31 \mathrm{~g})$ followed by Glycera sp $(20.99 \mathrm{~g})$ and $P$. cultrifera (11.99 g) and the major fatty acids profile (Fig. 3) composition was grouped in three polychaete species as Saturated Fatty Acid (SFA), it was reported with Palmic acid (16:0), it was showed that $4.367 \mathrm{~g}, 3.030 \mathrm{~g}$, and $1.067 \mathrm{~g}$; Margaric acid (17:0) was showed that 2.019 $\mathrm{g}, 1.220 \mathrm{~g}$, and $0.246 \mathrm{~g}$; and the Stearic acid (18:0) was showed that $8.640 \mathrm{~g}, 4.580 \mathrm{~g}$, and $4.055 \mathrm{~g}$, in N. virens, Glycera sp, and P. cultrifera, respectively. Monounsaturated Fatty Acid 
(MUFA) was reported with Oleic acid $(18: 1)$ and the maximum value was recorded in $N$. virens $(8.030 \mathrm{~g})$ followed by Glycera sp $(3.130 \mathrm{~g})$ and P. cultrifera $(2.344 \mathrm{~g})$; Polyunsaturated Fatty Acid (PUFA) was reported with Linoleic acid (18:2) and the maximum value was recorded in Glycera sp (5.310 g) followed by P. cultrifera (1.992 g) and N. virens (1.330 g); Alpha-linolenic acid $(18: 3)$ the maximum content was recorded in $N$. virens $(6.830 \mathrm{~g})$ followed by Glycera sp $(3.210 \mathrm{~g})$ and $P$. cultrifera $(2.056 \mathrm{~g})$; and finally, Morotic acid $(18: 4)$ the maximum content was recorded in $N$. virens $(0.993 \mathrm{~g})$ followed by Glycera sp $(0.310 \mathrm{~g})$ and $P$. cultrifera $(0.111$ $\mathrm{g})$. In the present study the result of major fatty acids profile, showed that the Saturated Fatty Acid (SFA) content was higher when it compare to PUFA and MUFA in all three polychaetes and the maximum content was recorded in $N$. virens $(15.026 \mathrm{~g}, 9.153 \mathrm{~g}$, and $8.030 \mathrm{~g})$ followed by Glycera sp $(8.830 \mathrm{~g}, 8.830 \mathrm{~g}$, and $3.130 \mathrm{~g})$ and P. cultrifera $(5.368 \mathrm{~g}, 4.159 \mathrm{~g}$, and $2.344 \mathrm{~g})$, respectively. This SFA was dominant with stearic acid followed by palmitic acid and this similar has been made in P. cultrifera (Dorgham et al., 2015). This similar observation has been made by various authors in Nereis diversicolor (Bischoff, 2009) and in Nereis sp (Sunil Kumar Sahu et al., 2017) of Palmitic acid and Oleic acid. Among the PUFA group, alpha-linolenic acid was found higher in $N$. virens and this similar observation was found in Nereis sp (Sunil Kumar Sahu et al., 2017). The PUFA (particularly Omega-3 and Omega-6) plays an important role in the membrane structures, metabolic processes, and precursors to biosynthetic pathways to involve in the in vivo supply of the sex steroids (Izquierdo et al., 2001; Nguyen et al., 2012; Palmer et al., 2014). Recently, polychaete fatty acids were evaluated as potential inhibitor against human glioblastoma multiforme (Reena Singh et al., 2013). Hence, the polychaete worms are an important vector for the transfer of essential fatty acids to fish and crustaceans in aquaculture.

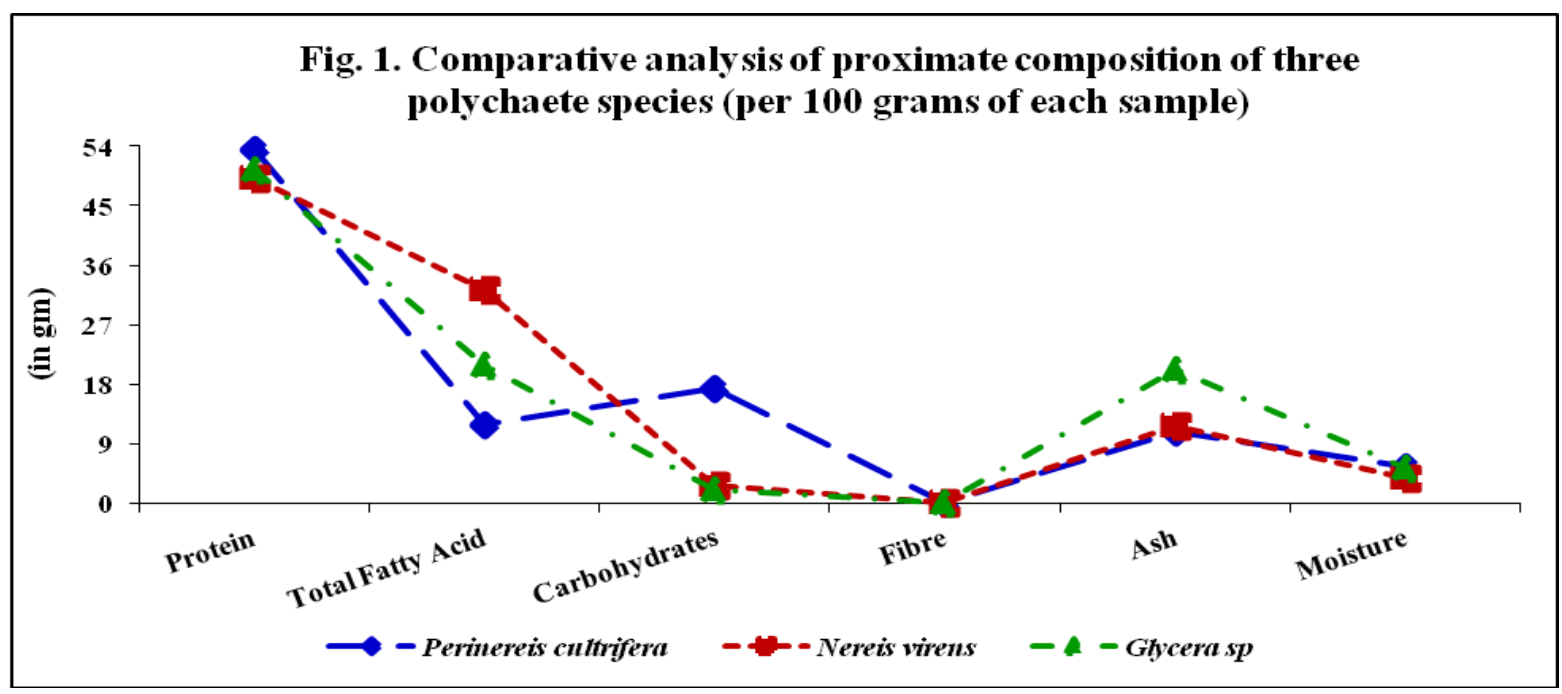

Fig.1.Comparative analysis of proximate composition of three polychaete species (per 100 grams of each sample )

In the present study the maximum ash content was recorded in Glycera sp (20.32 g) followed by $N$. virens $(11.73 \mathrm{~g}$ ) and $P$. cultrifera $(10.91 \mathrm{~g})$ and this similar observation was reported in P. cultrifera (Dorgham et al., (2015) and in P. nuntia (Techaprempreecha et al., $2011)$ and the maximum fiber content was record in Glycera sp $(0.11 \mathrm{~g})$ and $P$. cultrifera $(0.10 \mathrm{~g})$ followed by $N$. virens $(0.05 \mathrm{~g})$ (Fig. 1) and similar observation was recorded in Nereis sp (Wibowo et al., 2019). The maximum carbohydrate content was recorded in $P$. cultrifera $(17.53 \mathrm{~g})$ followed by $N$. virens $(2.67 \mathrm{~g})$ and Glycera sp $(2.04 \mathrm{~g})$. This similar observation has 
been made in $P$. cultrifera from the Egyptian Mediterranean Coast (Dorgham et al., 2015), in Nereis sp (Sunil Kumar Sahu et al., 2017) and in N. virens (Brown et al., 2011). Carbohydrates are also excellent binders in diet formulation (Wouters et al., 2001) and play an important role in glycogen accumulation in the hepatopancreas and also act as binders and transport of nutrients in the hemolymph (Harrison, 1997). The complex sugars and polysaccharides are used more effectively than simple sugars (Deshimaru and Yone, 1978). However, they can be used as source of energy with protein-sparing and lipid-sparing effects.

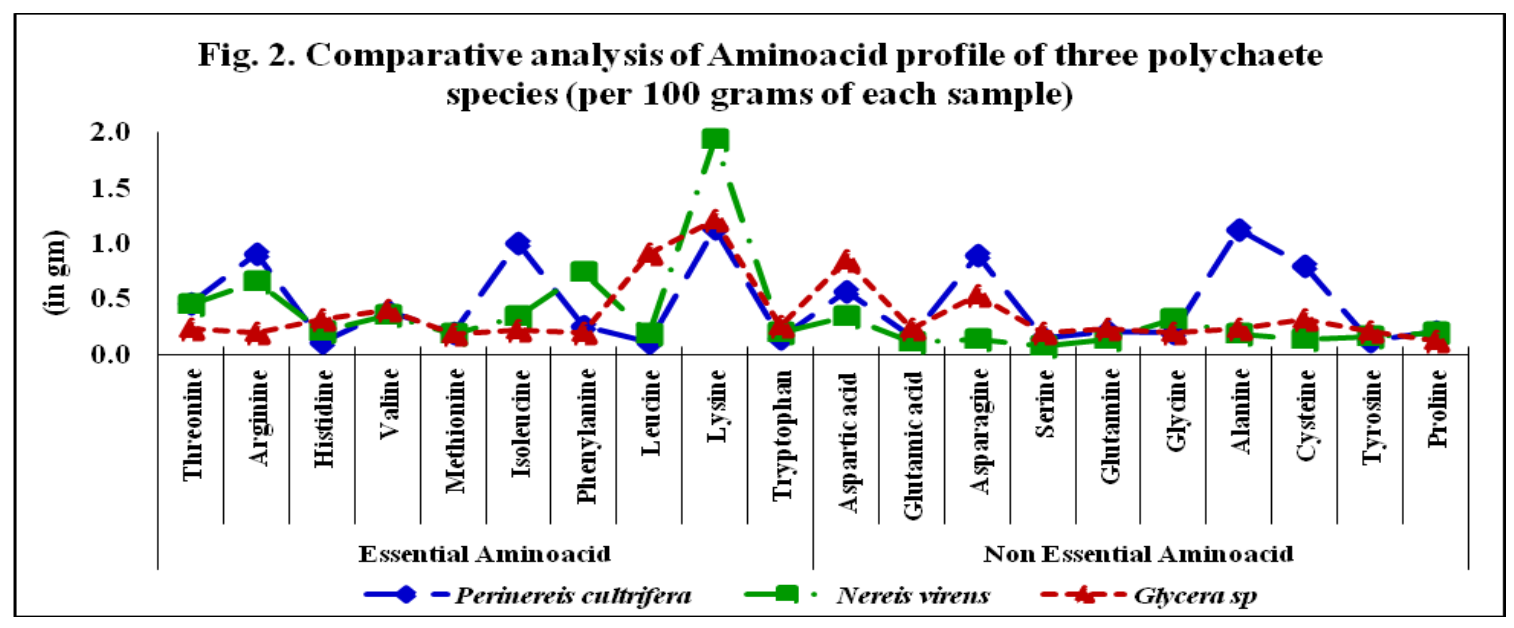

Fig.2.Comparative analysis of Aminoacid profile of three polychaete species (per 100 grams of each sample )

The results of the amino acids profile (Fig. 2) in three polychaete species was reported with 10 essential amino acids (EAA) and 10 non-essential amino acids (NEEA). The maximum essential amino acids content was recorded (EAA) in $N$. virens $(5.2716 \mathrm{~g})$ followed by $P$. cultrifera $(4.7009 \mathrm{~g})$, and Glycera sp $(4.1204 \mathrm{~g})$ and the maximum NEAA content was recorded in $P$. cultrifera $(4.4212 \mathrm{~g})$, followed by Glycera sp $(3.1265 \mathrm{~g})$ and $N$. virens $(1.8041 \mathrm{~g})$. In $P$. cultrifera, the maximum content of EAA was reported with lysine $(1.1356 \mathrm{~g})$ and minimum value with histidine $(0.1095 \mathrm{~g})$ and the maximum content of NEAA was reported with alanine $(1.1245 \mathrm{~g})$ and minimum content with tyrosine $(0.1195 \mathrm{~g})$; in $N$. virens, EAA reported maximum with lysine $(1.9347 \mathrm{~g})$ and minimum with leucine $(0.1895 \mathrm{~g})$ and NEAA reported maximum with aspartic acid $(0.3456 \mathrm{~g})$ and minimum with serine $(0.0784 \mathrm{~g})$ and Glycera sp, EAA reported maximum with lysine $(1.2057 \mathrm{~g})$ and minimum with methionine $(0.1903)$ and NEAA reported maximum with aspartic acid $(0.8457 \mathrm{~g})$ and minimum value of proline $(0.1193$ g). 


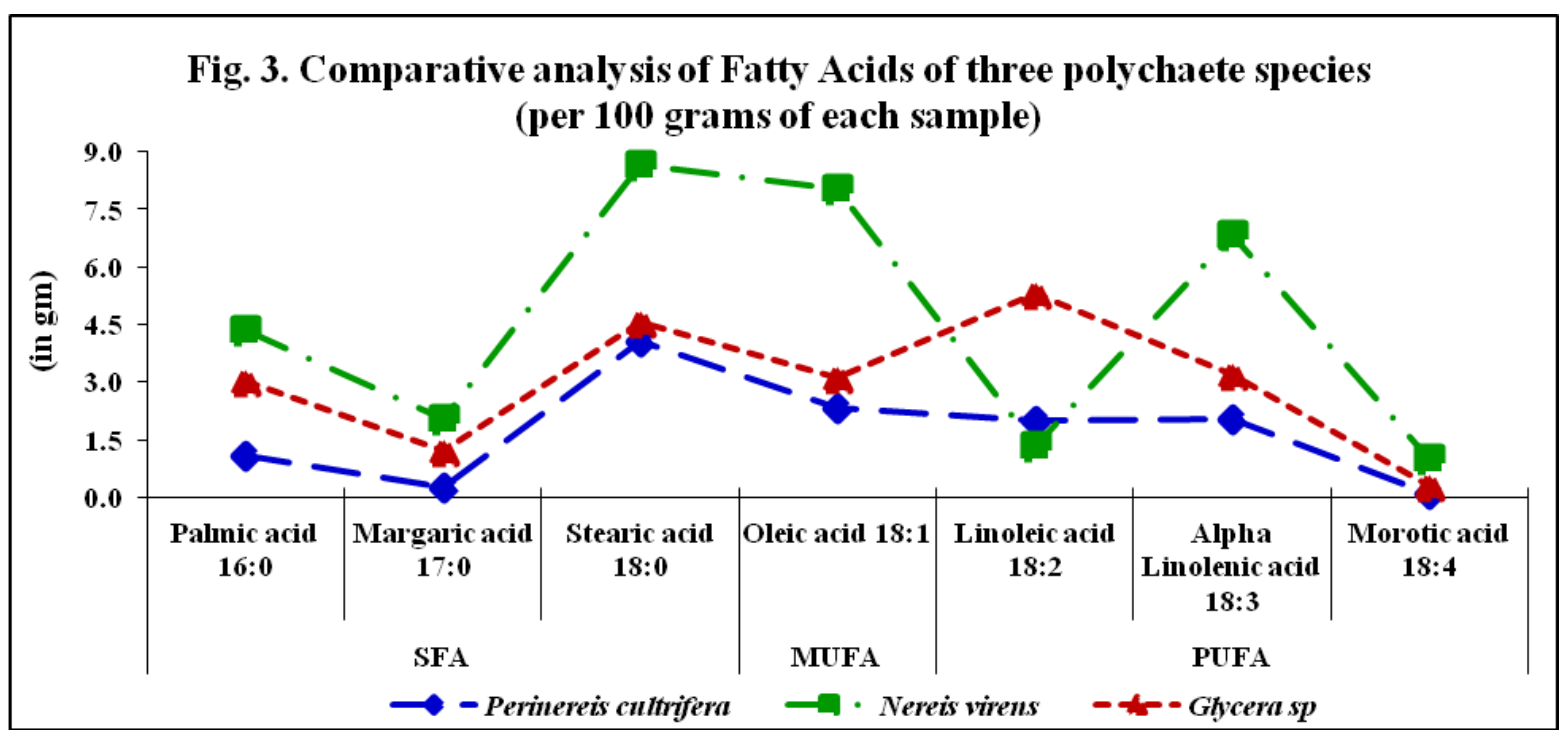

Fig .3.Comparative analysis of Fatty acid of three polychaete species (per 100 grams of each sample )

In this study, EAA was recorded higher content when it compare to NEAA in all the three species of polychaete. In the EAA the most dominant amino acids are lysine, arginine, and isoleucine and in the NEAA are cysteine, alanine, asparagine, and aspartic acid whereas the lesser EAA and NEAA are methionine and serine, respectively. This similar observation has been reported in $P$. cultrifera (Dorgham et al., 2015) and in mariculture wastewater polychaete, $P$. helleri (Palmer et al., 2014). Essential amino acid like leucine can stimulate the protein synthesis was reported by Volek, (2009) and the lysine and tyrosine have essential roles in reproductive functions and nutrition of developing gametes (Fischer et al., 1996; Hoeger and Abe, 2004). On the other hand, the NEAAs such as alanine, proline, and glycine are considered as osmolytes in P. cultrifera (Jeuniaux et al., 1961) and in other polychaetes and marine invertebrates (Hoeger and Abe, 2004, Kube et al. 2007). Alternatively, serine is involved in methyl group transfer, which is responsible for different processes in the cell and contributes to the formation of S-adenosylmethionine, the methyl donor (Amelio et al., 2014).

Three species of polychaetes showed difference among vitamins (Fig. 4) composition: Vitamin B1 (Thiamine) content was maximum in P. cultrifera $(1.55 \mathrm{mg})$ followed by Glycera sp $(1.34 \mathrm{mg})$, and $N$. virens (in traces); Vitamin B2 (Riboflavin) content was maximum in $P$. cultrifera $(1.29 \mathrm{mg})$ followed by $N$. virens $(0.62 \mathrm{mg})$ and Glycera sp $(0.45 \mathrm{mg})$; Vitamin B3 (Niacinamide) level was maximum in P. cultrifera $(1.34 \mathrm{mg})$ followed by $N$. virens $(0.45 \mathrm{mg})$ and Glycera sp (0.34 mg) about; Vitamin B6 (Pyridoxamine) level was maximum in Glycera sp $(1.56 \mathrm{mg})$ followed by $P$. cultrifera $(0.50 \mathrm{mg})$ and $N$. virens $(0.10 \mathrm{mg})$; Vitamin B9 (Folic acid) content was maximum in $N$. virens $(0.003)$ followed by Glycera $\mathrm{sp}(0.002 \mathrm{mg})$ and $P$. cultrifera (0.001); Vitamin B12 (Cyanocobalamin) content was maximum in Glycera sp (1.22 mg), whereas $P$. cultrifera and $N$. virens in traces; Vitamin A content was maximum in $P$. cultrifera $(0.357 \mathrm{mg})$ followed by $N$. virens $(0.017 \mathrm{mg})$ and Glycera sp $(0.016 \mathrm{mg})$; likewise, Vitamin $\mathrm{E}$ content was maximum in $P$. cultrifera $(3.88 \mathrm{mg})$ followed by $N$. virens $(2.91 \mathrm{mg})$ and Glycera $\mathrm{sp}(1.33 \mathrm{mg})$; and finally, Vitamin $C$ reported with maximum in $N$. virens $(20.1 \mathrm{mg})$ followed by Glycera sp $(11.9 \mathrm{mg})$ and $P$. cultrifera $(0.78 \mathrm{mg})$. Not much study has been conducted on vitamin and mineral content in polychaete. In vitamin study, P. cultrifera, $N$. virens and Glycera sp showed higher content of vitamins $A, B 1$, and $E$ and less in vitamin $C$ and this similar observation has been made in P. nuntia (Techaprempreecha et al., 2011). 


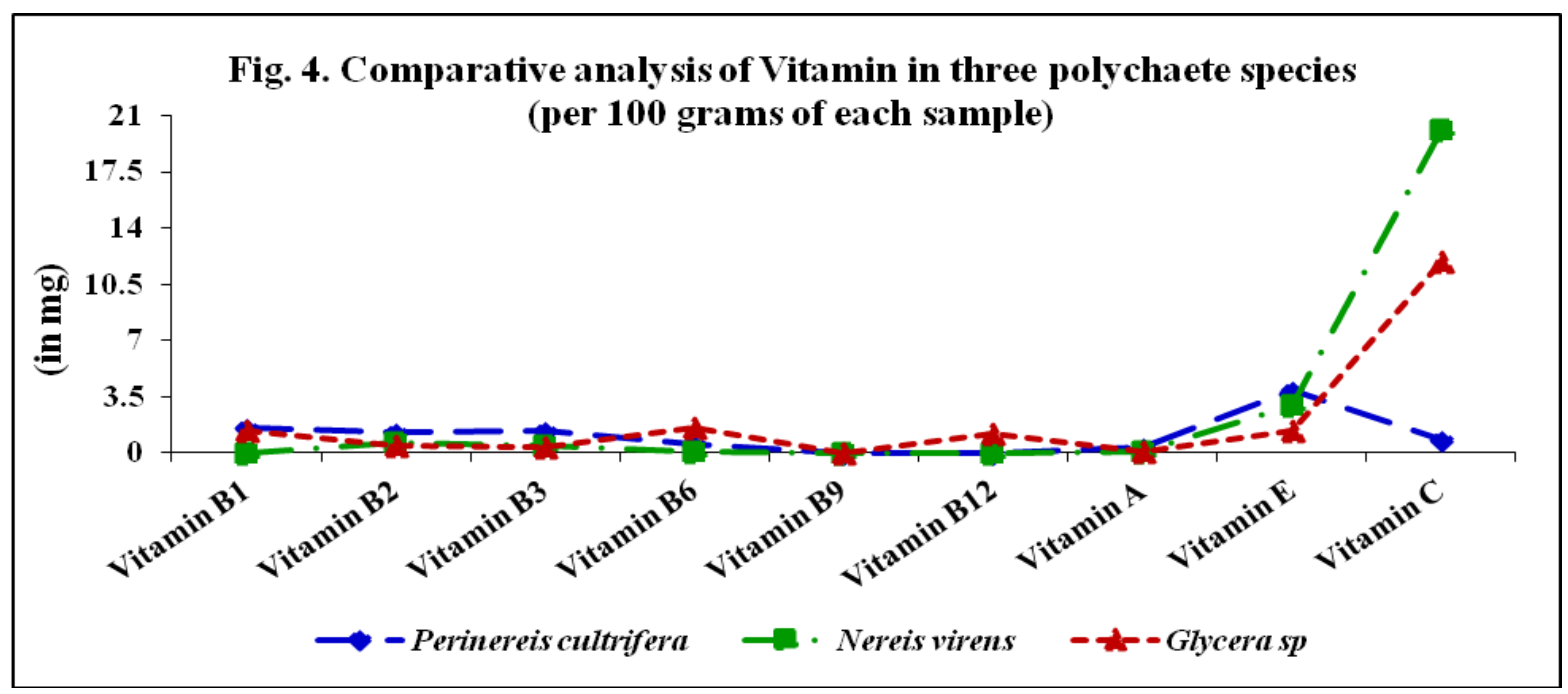

Fig .4.Comparative analysis of Vitamin in three polychaete species (per 100 grams of each sample )

The fat-soluble vitamins $A, D$, and $E$ are essential to support the growth of the shrimp (He et al., 1992). Dietary levels of thiamin (B1), riboflavin (B2), niacin, vitamin B6, vitamin B12, choline, inositol, and ascorbic acid were also been recommended for the maximum growth of the several species of shrimp ( $D^{\prime}$ Abramo and Conklin, 1992). Earlier studies have been conducted in shrimp with vitamin $\mathrm{E}$ showed that the improvement of the percentage of normal rate of sperm and ovarian maturation (Chamberlain, 1988), whereas Alava et al., (1993b) proved that the ovarian maturation was retarded when the deficiency of any one of these vitamins like $E, A$, and $C$. In the present study, all the three polychaete species were recorded with required quantity of vitamin as essential nutrition for shrimp aquaculture.

The mineral (Fig. 5) composition varied among the three polychaete species, each of 100 grams: Calcium was maximum in Glycera sp $(84.3 \mathrm{mg}$ ) followed by $N$. virens $(56.7 \mathrm{mg})$ and $P$. cultrifera $(25.6 \mathrm{mg}$ ); likewise, Magnesium content was maximum in Glycera sp (25.7 $\mathrm{mg})$ followed by $N$. virens $(17.32 \mathrm{mg})$ and $P$. cultrifera $(12.9 \mathrm{mg})$; Zinc content varied from species as $N$. virens $(1.79 \mathrm{mg})$, Glycera sp $(1.55 \mathrm{mg})$, and $P$. cultrifera $(1.13 \mathrm{mg})$; Iron content showed maximum in $P$. cultrifera $(4.21 \mathrm{mg})$ followed by Glycera $\mathrm{sp}(3.46 \mathrm{mg})$ and $N$. virens $(1.90 \mathrm{mg})$; Sodium content varied maximum in $N$. virens $(156.70 \mathrm{mg}), P$. cultrifera $(147.50$ $\mathrm{mg})$, and Glycera sp (145.20 mg); Potassium was maximum in Glycera sp (201.30 mg) followed by $P$. cultrifera $(94.30 \mathrm{mg}$ ) and $N$. virens $(90.30 \mathrm{mg})$; and Sodium level was maximum in $N$. virens $(1456.70 \mathrm{mg})$ followed by Glycera sp $(894.60 \mathrm{mg})$ and $P$. cultrifera $(456.60 \mathrm{mg})$. Mineral content was dominant with chloride of all the three species of polychaete and this similar study has been made in $P$. nuntia (Techaprempreecha et al., 2011). According to Harrison (1990) that the mineral deficiencies or imbalances could be affected the crustacean reproduction negatively and the physiological stresses could be trigger the oocyte resorption or reduce the reproductive fitness of the broodstock. Additionally, the minerals malnutrition are could cause the altered composition and the quality of eggs. However, the studies on mineral requirements for shrimp brood stock was very less and in most of the studies the artificial diets the mixer of the minerals were formulated, especially to fortify with calcium, phosphorus, magnesium, sodium, iron, manganese, and selenium (Chamberlain, 1988; Alava et al., 1993 a, b; Marsden et al., 1997; Mendoza et al., 1997; Xu et al., 1994). 


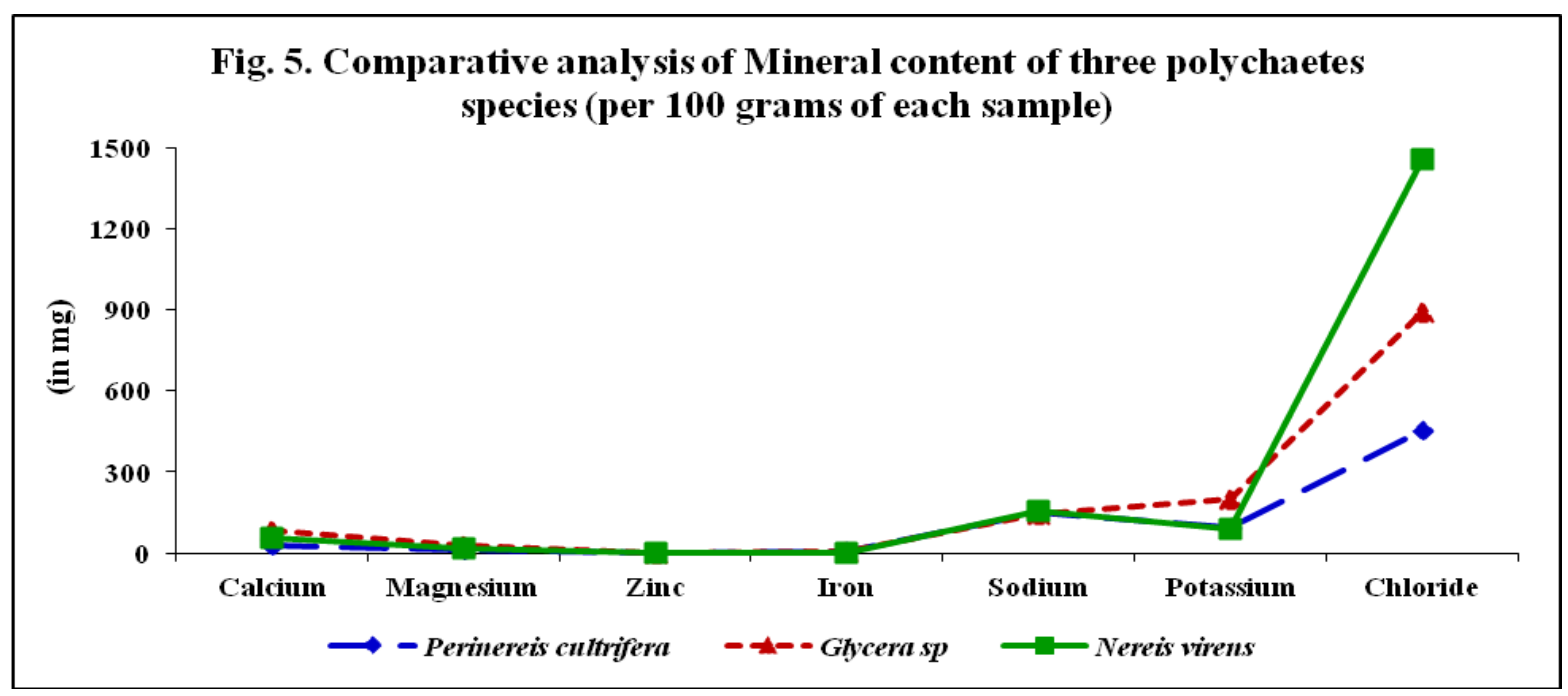

Fig .5.Comparative analysis of Mineral content of three polychaete species (per 100 grams of each sample

From the earlier studies, it was evidently understood that nutrition is an important factor in growth and breeding of penaeid shrimps, and yet, knowing shrimp nutrition requirements is essential for successful management of broodstocks (Alireza Salarzadeh, 2014). The polychaetes are likely to become increasingly important as a resource in relation to the development of aquaculture for crustacea (Milada Safarik, 2007) since it has been found that polychaetes can provide a nutritionally correct balance of polyunsaturated fatty acids, which are essential for egg maturation in cultured prawns (Lytle et al., 1990) or can provide other factors are essential for egg maturation (Croz et al., 1990). In addition, polychaete worms may cause better absorption of chemical compositions like cholesterol and long chain unsaturated fatty acids (HUFA), which are effective for growth of ovary and production of eggs with high quality (Alireza Salarzadeh, 2014) and also diets that lack essential fatty acids delay shrimp growth (Millinema et al., 1986, Sudaryono et al., 1995). The preference of polychaetes as feed for crustaceans is attributed to their contents of a suitable balance of nutrients and several other factors promoting crustacean reproduction (Palmer et al. 2014). This constraint arises because the most valuable cultured crustaceans and fish all require polyunsaturated fatty acids (PUFA) in their diet (Izquierdo et al. 2001), especially for the production of viable young ones. However, the nutritional value of polychaetes as well as other diets can vary with species, season of harvest and life stage (Chimsung, 2014).

\section{ACKNOWLEDGEMENTS}

The authors express their thankfulness to the financial support for this research work under RUSA-Phase 2.0 scheme, Govt of India, Department of Oceanography and Coastal Area Studies, Alagappa University, Karaikudi.

\section{REFERENCE}

Alava, V.R., Kanazawa, A., Teshima, S., Koshio, S., 1993a. Effect of dietary phospholipids and ny3 highly unsaturated fatty acids on ovarian development of Kuruma prawn. Nippon Suisan Gakkaishi 59 (7): 345-351. 
Alava, V.R., Kanazawa, A., Teshima, S., Koshio, S., 1993b. Effect of dietary vitamins A, E and $C$ on the ovarian development of Penaeus japonicus. Nippon Suisan Gakkaishi 59 (7), 1235-1241.

Alireza Salarzadeh, 2014. The Effects of Different Diets on Ovary Maturation and Spawning of Pond-reared White Indian Shrimp (Fenneropenaeus indicus). New York Science Journal; $7(8)$.

Amelio, I., F. Cutruzzola, A. Antonov, M. Agostini and G. Melino. 2014. Serine and glycine metabolism in cancer. Trends in Biochemical Sciences 30(4): 191-198.

AOAC Method 985.29., 1990. Total dietary fiber in foods. Enzymatic - gravimetric method. Official Methods of Analysis of the Association of Official Analytical Chemists, 15th ed. The Association: Arlington, VA.

Batista, F. M., Fidalgo E Costa, P., Ramos, A., Passos, A. M., Poussao Ferreira, P. and Cancela Da Fonseca, L. 2003. Production of the ragworm Nereis diversicolor (O. F. Muller 1776), fed with a diet for gilthead seabream Sparus auratus L., 1758: survival, growth, feed utilization and oogenesis. Boletin Insitituto Espanol de Oceanografia, 19, 447-451.

Beesley, P. L., Ross, G. J. B. and Glasby, C. J. 2000. Polychaetes and allies: the southern synthesis. Fauna of Australia. Melbourne, CSIRO Publishing.

Bischoff, A.A, P. Fink and U. Waller. 2009. The fatty acid composition of Nereis diversicolor cultured in an integrated recirculated system: Possible implications for aquaculture. Aquaculture 296: 271-276.

British Pharmacopeia. 2007. British Pharmacopoeia Commission. Volumes: 6 nos. Pp. 1148.

Brown, N., S. Eddy and S. Plaud. 2011. Utilization of waste from a marine recirculating fish culture system as a feed source for the polychaete worm, Nereis virens. Aquaculture 322/ 323: 177-183.

Cardinaletti, G, Mosconi, G., Salvatori, R., Lanari, D., Tomassoni, D., Carnevali, O. and Polzonetti-Magni, A.M. 2009. Effect of dietary supplements of mussel and polychaetes on spawning performance of captive sole, Solea solea (Linnaeus, 1758). Animal Reproduction Science, 113(1- 4): 167-176. doi.org/10.1016/j.anireprosci.2009.06.003

Chamberlain, G.W., 1988. Stepwise investigation of environmental and nutritional requirements for reproduction of penaeid shrimp. PhD dissertation, Department of Wildlife and Fisheries Science, Texas A\&M University, TX, USA.

Chen, L.C., 1990. Aquaculture in Taiwan. Fishing News Books, Oxford: 273 pp.

Chimsung, N. 2014. Maturation diets for black tiger shrimp (Penaeus monodon) broodstock: a review. Songklanakarin Journal of Science and Technology 36(3): 265-273.

Coman, G.J., Arnold, S.J., Callaghan, T.R. and Preston, N.P., 2007. Effect of two maturation diet combinations or reproductive performance of domesticated Penaeus monodon. Aquaculture 213, 75-83.

Creaser, E. P., D. A. Clifford, M. J. Hogan, and D. B. Simpson. 1983. A commercial sampling program for sandworms, Nereis virens, and bloodworms, Glycera dibranchiata, harvested along the Maine coast. NOAA Technical Report NMFS SSRF 767.

Croz, L., Wong, L., Justine, G. and Gupta, M. 1988. Prostaglandins and related compounds from the polychaete worm Americonuphis reesei Fauchald (Onuphidae) as possible inducers of gonad maturation in Penaeid shrimps. Rev. Trop. 36: 331-332.

D'Abramo, L.R., Conklin, D.E., 1992. New developments in the understanding of the nutrition of penaeid and caridean species of shrimp. In: Browdy, C.L., Hopkins, S.J. (Eds), Swimming Through Troubled Water. Proceedings of the Special Session on Shrimp Farming, Aquaculture '95, World Aquaculture Society, Baton Rouge, LA, USA, pp. 95107. 
Deshimaru, O. and Yone, Y., 1978. Effect of dietary carbohydrate sources on the growth and feed efficiency of prawn. Bull. Jpn. Soc. Sci. Fish. 44, 1161-1163.

Dorgham, M.M., R Hamdy, H.H. Al-Rashidy and M.M, Atta. 2015. Biochemical composition of the nereidid Perinereis cultrifera from the Egyptian Mediterranean Coast. Revista de Biología Marina y Oceanografía, Vol. 50, N03: 535-543.

Fischer, A, A.W.C. Dorresteijn and U. Hoeger. 1996. Metabolism of oocyte construction and the origin of histospecificity in the cleaving egg. Lessons from nereid annelids. International Journal of Developmental Biology 40: 421-430.

Gambi, M. C., Castelli, A., Giangrande, A., Lantera, P., Prevedelli, D. and Vandini, R. Z. 1994. Polychaetes of commercial and applied interest in Italy: an overview. Pages 593-603 in J. C. Dauvin, L. Laubier and D. J. Reish, eds. Actes de la 4ème Conférence Internationale des Polychètes. Mémoires du Muséum National d'Histoire Naturelle.

Harrison K.E. 1997. Broodstock nutrition and maturation diets. In: D'Abramo LR, DE Conklin \& DM Akiyama (eds). Advances in world aquaculture 6: Crustacean nutrition, pp. 390408. World Aquaculture Society, Baton Rouge.

Harrison, K.E. 1990. The role of nutrition in maturation, reproduction and embryonic development of decapod crustaceans: a review. Journal of Shellfish Research; 9 (9): pp. $1-18$.

He, H., Lawrence, A.L. and Liu, R., 1992. Evaluation of dietary essentiality of fat-soluble vitamins, $A, D, E$ and $K$ for penaeid shrimp Penaeus vannamei. Aquaculture 103, 77185.

Hoeger, U. and H. Abe. 2004. b-Alanine and other free amino acids during salinity adaptation of the polychaete Nereis japonica. Comparative Biochemistry and Physiology, Part A 137: $161-171$.

Huang, J., Jiang, S., Lin, H., Zhou, F. and Ye, L. 2008. Effect of dietary highly unsaturated fatty acids and astaxanthin on the fecundity and lipid content of pond reared Penaeus monodon (Fabricius) broodstock. Aquaculture Research, 39, 240- 251. doi.org/10.1111/j.1365-2109.2007.01868.x

Indian Pharmacopeia. 2007. The Indian Pharmacopoeia Commission, Ghaziabad.

Izquierdo M.S., H. Fernandez-Palacios and A.G.J. Tacon. 2001. Effect of broodstock nutrition on reproductive performance of fish. Aquaculture 197: 25-42.

Klawe, W. L., and L. M. Dickie. 1957. Biology of the bloodworm, Glycera dibranchiata Ehlers, and its relation to the bloodworm fishery of the Maritime Provinces. Fisheries Research Board of Canada Bulletin 115:37.

Kristensen, E., Hjorth, M. and Andersen, T. K. 1985. The impact of polychaetes (Nereis virens Sars) burrows on nitrification and nitrite reduction in estuarine sediments. Journal of Experimental Marine Biology and Ecology, 85, 75-91.

Kube S, A Sokolowski, JM Jansen and D Schiedek. 2007. Seasonal variability of free amino acids in two marine bivalves, Macoma baltica and Mytilus spp., in relation to environmental and physiological factors. Comparative Biochemistry and Physiology, Part A 147: 1015-1027.

Lawrence Evans. 2012. Dietary Supplements: Non-Botanicals USP27 - NF22 Page 2063. Pharmacopeial Forum: Volume No. 28 (5) Page 1545.

Lytle, J. S., T. F. Lytle and J. T. Ogle. 1990. Polyunsaturated fatty acid profiles as a comparative tool in assessing maturation diets of Penaeus vannamei. Aquaculture, 89: 287-299.

Marsden, G.E., McGaren, J.J., Hansford, S.W. and Burke, M.J. 1997. A moist artificial diet for prawn broodstock: its effect on the variable reproductive performance of wild caught Penaeus monodon. Aquaculture 149, 145-156. 
Mendoza, R., Revol, A., Fauvel, C., Patrois, J., Guillaume, J.C., 1997. Influence of squid extracts on the triggering of secondary vitellogenesis in P. vannamei. Aquacult. Nutr.3, 55-63.

Meunpol, O., Meejing, P. and Piyatiratitivorakul, S. 2005. Maturation diet based on fatty acid content for male Penaeus monodon (Fabricius) broodstock. Aquac. Res. 36, 1216-1225.

Milada Safarik, 2007. Aquabait Marine Worm Farm and Sustainability Case Study in Aquaculture. Aquabait, Pty Ltd.

Millamena O.M., Primavera J.H., Pudadera R.A., Caballera R.V. 1986. The effect of diet of the reproductive performance of pond-reared Penaeus monodon Fabricius broodstock; In Maclean J.L., Dizon L.B. and Hosilos L.V. (eds.); The First Asian Fisheries Forum; Manila, Philippines. pp. 593-596.

Murugesan, P., S. Elayaraja, S. Vijayalakshmi and T. Balasubramanian, 2011. Polychaetes - a suitable live feed for growth and colour quality of the clownfish, Amphiprion sebae (Bleeker, 1953). Journal of the Marine Biological Association of India, 53(2): pp: 1-7

Navedo, J.G. and Masero, J.A. 2007. Measuring potential negative effects of traditional harvesting practices on waterbirds: a case study with migrating curlews. Animal Conservation.

Nguyen, B.T., S. Koshio, K. Sakiyama, M. Ishikawa, S. Yokoyama and M.A. Kader. 2012. Effects of polychaete extracts on reproductive performance of kuruma shrimp, Marsupenaeus japonicus Bate. Part II. Ovarian maturation and tissue lipid compositions. Aquaculture 334/337: 65-72.

Olive, P. J. W., 1999. Polychaete aquaculture and polychaete science: a mutual synergism. Hydrobiologia 402: pp. 175-183.

Olive, P.J.W., N. Bury, P.B.D. Cowin and R.R. Smithard. 1992. Commercial production of polychaetes for angling: implications for mainstream aquaculture. Spl. Publ. Eur. Aquac. Soc., 14: 241-242.

Palmer, P.J., S. Wang, A.Houlihan and I.Brock. 2014. Nutritional status of a nereidid polychaete cultured in sand filters of mariculture wastewater. Aquaculture Nutrition 20(6): 675691.

Reena Singh, Sunil Kumar Sahu and Muthusamy Thangaraj. (2013). Polychaete fatty acids as potential inhibitor against human glioblastoma multiforme. International Journal of Recent Scientific Research, 4(10):1519-1524.

Sarda Borroy, R. 1989. Informe Tecnico. Escuela Spenser de Administration y Direccion de Empresas (ESADE): 190 pp.

Scaps, P. 2002. A review of the biology, ecology and potential use of the common ragworm Hediste diversicolor (O. F. Muller) (Annelida:Polychaeta). Hydrobiologia, 470, 203-218.

Scaps, P., 2003. Exploitation et élevage des vers marins. Bulletin de la Société zoologique de France, 128 (1-2): 21-33.

Shiau, S., 1998. Nutrient requirements of penaeid shrimps. Aquaculture 164, 77-93.

Soraphat Panakorn, 2015. Polychaetes for shrimp broodstock maturation, AQUA Culture Asia Pacific Magazine, pp: 6-11.

Stoner, A. W. and Acevedo, G. 1990. The macroinfaunal community of a tropical estuarine lagoon. Estuaries, 13, pp: 174-181.

Sudaryono A., Hoxey, Kailis S.G., Evans L.H. 1995. Investigation of alternative protein sources in practical diets for juvenile shrimp Penaeus monodon, Aquaculture. 134: Pp. 313-323.

Sunil Kumar Sahu, Reena Singh, Perumal Murugesan, Samikkannu Muthuvelu and Kandasamy Kathiresan, 2017. Biochemical studies on the live feed polychaete, Nereis sp., in relation to maturity stages. Indian Journal of Geo Marine Sciences, Vol. 46 (03): pp. 591- 596. 
Techaprempreechaa, S., N. Khongchareonpornb, C. Chaicharoenpongb, P. Aranyakanandac, S. Chunhabunditc, and A. Petsoma. 2011. Nutritional composition of farmed and wild sandworms, Perinereis nuntia, Animal Feed Science and Technology, 169: 265- 269.

Vijayan, K.K, V. Stalin Raj, C.P. Balasubramaniyan, S.V. Alavandi, V. Thillai Sekar and T.C. Santiago. 2005. Polycheate worms a vector for White Spot Syndrome Virus (WSSV). Disease of Aquatic organisms Vol. 63: 107-111.

Volek, J.S. 2009. Additional leucine not required for whey protein. Applied Physiology, Nutrition and Metabolism 34(2): 151-161.

Wibowo E.S., E.S. Palupi, IGA A. R. Puspitasari and Atang. 2019. Metabolism and nutritional content of polychaeta Nereis sp. with maintenance salinity and different types of feed.

Xu, X.L., Ji, W.L., Castell, J.D and O'Dor, R.K., 1994. Influence of dietary lipid sources on fecundity, egg hatchability and fatty acid composition of Chinese prawn (Penaeus chinensis) broodstock. Aquaculture 119, 359-370.

Received: 30 ${ }^{\text {th }}$ April 2020; Accepted: 07th August 2020; Published: 14th September 2020. 